Research Article

\title{
Pengaruh Suhu dan Jenis Perekat Terhadap Kualitas Biobriket dari Ampas Kopi dengan Metode Torefaksi
}

\section{The Influence of Temperature and Types of Adhesive on Biobriquettes from Coffee Pulp with} Torrefaction Method

\author{
Vibianti Dwi Pratiwi ${ }^{*}$, Iman Mukhaimin ${ }^{2)}$ \\ ${ }^{1)}$ Institut Teknologi Nasional Bandung, Teknik Kimia, Indonesia \\ ${ }^{2)}$ Politeknik Kelautan dan Perikanan Karawang, Teknik Pengolahan Produk Perikanan, \\ Indonesia
}

*correspondence email: vibiantidwi@itenas.ac.id

\begin{abstract}
Abstrak
Penggunaan energi biomassa sebagai sumber energi alternatif terbarukan diupayakan untuk mengurangi emisi $\mathrm{CO}_{2}$. Ampas kopi merupakan limbah biomassa yang dihasilkan dari proses produksi yang digunakan sebagai raw material dalam pembuatan biobriket. Limbah biomassa mempunyai calorific value yang relatif tinggi jika diolah menjadi biobriket dengan perekat. Jenis perekat yang digunakan adalah tepung tapioka dan getah pinus dengan komposisi tepung tapioka yang digunakan $0 \%$, 10\% dan $20 \%$ sedangkan jumlah perekat getah pinus $0 \%, 10 \%, 20 \%$, dan $40 \%$. Dengan mengetahui pengaruh jenis dan jumlah perekat dalam pembuatan biobriket menggunakan metode torefaksi, diharapkan limbah ampas kopi dapat menjadi biomassa sebagai energi alternatif. Penelitian dilakukan pada suhu torefaksi yaitu $200{ }^{\circ} \mathrm{C}, 250{ }^{\circ} \mathrm{C}$ dan $300{ }^{\circ} \mathrm{C}$. Suhu torefaksi yang optimal untuk pembuatan biobriket dari ampas kopi adalah $300{ }^{\circ} \mathrm{C}$ dengan perekat getah pinus $40 \%$ yang menghasilkan biobriket lebih padat dan tidak mudah hancur dengan nilai kalori sebesar $6124 \mathrm{kal} / \mathrm{gr}$.
\end{abstract}

Kata kunci: ampas kopi; biobriket; bioenergi; getah pinus; torefaksi

\begin{abstract}
Biomass energy as a renewable alternative energy source is made to reduce $\mathrm{CO}_{2}$ emissions. Coffee grounds are biomass waste produced from the production process which is used as raw material in making biobriquettes. Biomass waste has a relatively high calorific value if it is processed into biobriquettes with adhesive. The types of adhesive used were tapioca flour and pine resin with a composition of $0 \%, 10 \%$ and $20 \%$ tapioca flour used, while the amount of adhesive for pine resin was $0 \%, 10 \%, 20 \%$, and 40\%. By knowing the effect of the type and amount of adhesive in making biobriquettes using the torefaction method, it is hoped that coffee grounds waste can become biomass as an alternative energy. The types of adhesive used were starch and pine resin with starch's composition: $0 \%, 10 \%$, and 20\%, while amount of adhesive for pine resin: $0 \%, 10 \%, 20 \%$, and $40 \%$. The research was conducted at torrefaction temperatures: $200{ }^{\circ} \mathrm{C}, 250{ }^{\circ} \mathrm{C}$ and $300{ }^{\circ} \mathrm{C}$. The optimal torefaction temperature for make briquettes from coffee grounds is $300{ }^{\circ} \mathrm{C}$ using $40 \%$ pine resin adhesive so that produces biobriquette not easily destroyed with a calorific value of $6124 \mathrm{cal} / \mathrm{gr}$.
\end{abstract}

Keywords: biobriquette; bioenergy; coffee pulp; pine resin; torrefaction 
Pengaruh Suhu dan Jenis Perekat Terhadap Kualitas Biobriket dari Ampas Kopi dengan Metode Torefaksi

\section{Pendahuluan}

Indonesia merupakan salah satu negara berkembang yang memiliki potensi sumber daya dalam pengembangan sumber energi terbarukan, tetapi hanya sebagian kecil yang digunakan. Biomassa merupakan sumber energi terbarukan dan berkelanjutan yang memiliki potensi sangat besar yaitu 146,7 juta ton per tahun. Sementara potensi biomassa yang berasal dari sampah untuk tahun 2020 diperkirakan sebanyak 53,7 juta ton [1]. Biomassa membantu diversifikasi bahan bakar fosil seperti minyak bumi di dunia [2].

Berbagai upaya dilakukan untuk penghematan minyak bumi yang semakin menipis. Biobriket menjadi satu sumber energi alternatif terbarukan yang dapat digunakan untuk mengurangi permasalahan krisis energi. Limbah biomassa dikonversi menjadi biobriket atau pelet melalui teknologi sederhana yang relatif murah dan cocok dikelola oleh masyarakat dari kalangan menengah ke bawah maupun industri swasta [3].

Penggunaan biobriket sebagai bahan bakar padat menjadi salah satu solusi dalam menghemat pemakaian bahan bakar cair. Proses utama yang digunakan adalah penekanan tinggi pada temperatur tinggi, sehingga membentuk produk yang seragam. Pelet dapat diproduksi dengan mudah dari limbah kayu maupun bahan biomassa lainnya [4] .

Sektor agroindustri yang berkembang memiliki potensi untuk menghasilkan limbah pertanian dimulai dari proses persiapan raw material hingga proses produksi. Alternatif dalam memanfaatkan limbah argoindustri dengan mengubah limbah tersebut sebagai bahan bakar padat seperti biobriket. Hal tersebut bertujuan untuk meningkatkan nilai tambah atau menaikkan harga jual limbah argoindustri.

Ampas kopi termasuk limbah yang dapat menjadi bahan biomassa. Pada umumnya, ampas kopi langsung dibuang, hal ini juga menjadi salah satu masalah pencemaran lingkungan seperti pencemaran tanah. Ampas kopi dalam jumlah yang cukup banyak tersebut hanya sebagian kecil yang dimanfaatkan untuk pakan ternak atau penambah nutrisi tanaman. Namun beberapa daerah, limbah ampas kopi langsung dibakar di lapangan terbuka sehingga menyebabkan polusi baik udara maupun tanah dan menjadi limbah biomassa yang sangat perlu diperhatikan [5].

Ampas dari kopi memiliki kandungan kimia organik relatif tinggi dengan $\mathrm{pH}$ tinggi. Aplikasi terbaik limbah dari kopi dengan mengubahnya menjadi bahan bakar padat karena mengandung calorific value sebesar 20,9 MJ/kg pada dry basis dan $14,6 \mathrm{MJ} / \mathrm{kg}$ pada wet basis [6] Sumber unsur karbon pada ampas kopi cukup tinggi dan relatif mendekati berbagai limbah pengolahan argoindustri yang dijadikan bahan baku pembuatan bahan bakar padat biomassa pada perumahan maupun pabrik [7].

Khusna \& Susanto [8] telah memanfaatkan limbah kopi dan menghasilkan calorific value sebesar 24,117 MJ/kg untuk biobriket ampas kopi dan 28,364 MJ/kg untuk arang kopi. Berdasarkan perhitungan dalam riset tersebut, ampas kopi yang diambil dari suatu industri kopi, setelah dibakar dengan reaktor pirolisis menghasilkan biobriket 129,6 ton/bulan atau 4,32 ton/hari. Hal tersebut dapat diasumsikan $1 \mathrm{~kg}$ limbah kopi menghasilkan $40 \%$ arang ampas kopi, dan tanpa pirolisis menghasilkan sekitar 329 ton/bulan biobriket. Kualitas biobriket 
Pengaruh Suhu dan Jenis Perekat Terhadap Kualitas Biobriket dari Ampas Kopi dengan Metode Torefaksi

dengan dasar limbah dari kopi bergantung terhadap tingkat kepadatan, perbandingan campuran antara ampas kopi, arang kopi dan batu bara, jenis reaktor pembakaran dan udara berlebihnya [8].

Untuk menyempurnakan hasil pembriketan ada dua cara yaitu dengan atau tanpa pengikat (perekat). Pengikatan dibutuhkan supaya biomassa yang akan dibentuk menjadi biobriket lebih homogen selama teknik kompresi [14]. Tidak adanya perekat, biobriket menjadi mudah hancur saat dikeluarkan dari cetakan tersebut. Namun, adapula biomasa yang tidak membutuhkan perekat yaitu biomassa pada suhu dan tekanan relatif tinggi yang memiliki sifat sebagai perekat atau perekatnya sendiri [9].

Menurut Pratiwi [10] biobriket dari ampas kopi menggunakan perekat tapioka dengan metode pirolisi menghasilkan nilai kalor sebesar $7051 \mathrm{kal} / \mathrm{gr}$. Pembuatan biobriket dari ampas kopi dengan proses torefaksi dan penambahan perekat getah pinus dapat digunakan sebagai sumber energi alternatif bagi beberapa sektor di masyarakat. Selain penghasil kayu, potensi lain dari pohon pinus adalah getahnya, yang memiliki banyak manfaat yaitu sebagai bahan baku minyak terpentin, gondorukem, bahan sabun, perekat, cat, dan kosmetik [11].

Perbedaan antara getah pinus sebagai perekat dibandingkan dengan tapioka terletak pada kekuatan saat dijadikan briket. Perekat yang dihasilkan dari tapioka beragam kualitasnya tergantung dari proses pembuatannya terutama pencampuran air dan pada saat dimasak sampai mendidih. Sedangkan getah yang baik adalah getah yang segar biasanya mengandung banyak terpentin, berwarna putih bersih, dan bebas dari kotoran (daun, tatal, pasir, debu, dan sebagainya). Getah pinus merupakan senyawa kompleks yang bersifat asam dan sangat peka terhadap waktu dan rusak akibat penuaan atau aging [19].

Berdasarkan penelitian yang telah dilakukan sebelumnya, dengan mengetahui pengaruh jenis dan jumlah perekat dalam pembuatan biobriket menggunakan metode torefaksi, diharapkan dapat meningkatkan nilai jual ampas kopi dan dijadikan sebagai biomassa untuk energi alternatif. Kondisi optimum yang dilihat berdasarkan suhu torefaksi, jenis dan jumlah perekat yang diharapkan mampu menghasilkan kualitas biobriket dengan nilai kalor yang cukup tinggi sebagai bahan bakar alternatif.

\section{Metode Penelitian}

\subsection{Alat Penelitian}

Alat utama yang digunakan pada penelitian ini terdiri dari (1) Reaktor torefaksi, (2) heater, (3) kondensor, (4) wadah penampung, (5) elemen pemanas, (6) Tabung nitrogen, dan (7) pencetak briket. Skema alat yang digunakan pada penelitian dapat dilihat pada Gambar 1.

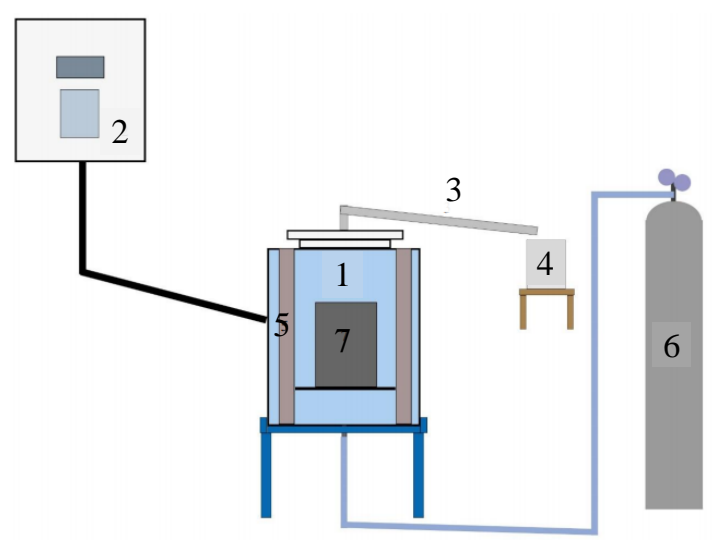

Gambar 1. Skema Alat Penelitian

Adapun beberapa alat penunjang yang digunakan untuk analisis seperti IKA C-2000 bomb calorimeter, saringan mesh (20-40 mesh), dan oven. 
Pengaruh Suhu dan Jenis Perekat Terhadap Kualitas Biobriket dari Ampas Kopi dengan Metode Torefaksi

\subsection{Bahan Penelitian}

Ampas kopi yang digunakan sebagai bahan dalam penelitian ini diambil dari sebuah toko minuman dengan menu utama berbasis kopi. Ampas kopi yang dibuang pada toko tersebut sekitar $5,7 \mathrm{~kg} / \mathrm{hari}$ yang kemudian dianalisis dengan uji ultimat dan nilai kalor di Laboratorium Tekmira Bandung. Bahan penunjang yang digunakan dalam penelitian antara lain perekat getah pinus dan tepung tapioka.

\subsection{Prosedur Pembuatan Briket}

Teknologi pembriketan adalah salah satu teknologi pemadatan dimana suatu bahan dikenai tekanan untuk membentuk produk yang mempunyai densitas lebih tinggi, moisture content yang relatif rendah, keragaman dalam ukuran dan sifatsifat bahannya [12]. Teknologi pembriketan yang digunakan pada penelitian ini adalah pembriketan bertekanan sedang dengan bantuan alat pemanas dan bahan pengikat atau perekat.

Sebelum proses torefaksi, ampas kopi yang diperoleh dimasukkan ke dalam oven untuk pengeringan selama kurang lebih 2 jam dengan suhu $105{ }^{\circ} \mathrm{C}$. Setelah kering, ampas kopi diayak pada 45-20 mesh. Selanjutnya 250 gram ampas kopi kering dicampur dengan perekat pada konsentrasi berbeda-beda yaitu 0\%, 10\%, $20 \%$ untuk jumlah tepung tapioka terhadap bahan baku dan 0\%, 10\%, 20\%, 40\% untuk getah pinus. Setelah biobriket dicetak menjadi silinder, kemudian dipanaskan dalam reaktor torefaksi selama 90 menit dengan mengalirkan gas nitrogen sehingga tidak ada udara dalam reaktor. Suhu torefaksi yang menjadi variabel penelitian adalah $200{ }^{\circ} \mathrm{C}, \quad 250{ }^{\circ} \mathrm{C}$, dan $300{ }^{\circ} \mathrm{C}$. Biobriket yang telah dipanaskan ditimbang dan siap dianalisis.

\subsection{Analisis Sampel}

\subsubsection{Analisis Kadar Air (SNI 01-6235-} 2000)

Ampas kopi sebanyak 2 gram dimasukkan ke dalam wadah yang telah ditimbang kemudian dimasukkan ke dalam oven dan dipanaskan pada suhu $105{ }^{\circ} \mathrm{C}$ selama 3 jam. Setelah 3 jam, selanjutnya dimasukkan ke dalam desikator selama 15 menit kemudian ditimbang. Kadar air dihitung meggunakan persamaan (1)

$\%$ kadar air $=\frac{(a-b)}{a} \times 100 \%$

$\%$ kadar air $=$ persentase kadar air terikat $(\%)$

$\mathrm{a}=$ massa sampel mula-mula (gram)

$\mathrm{b}=$ massa sampel setelah pemanasan pada 105 ${ }^{\circ} \mathrm{C}$ (gram)

\subsubsection{Analisis Kadar Abu (SNI 01-6235-} 2000)

Sampel ditimbang sebanyak 2 gram dan dimasukan kedalam wadah. Kemudian dimasukkan ke dalam tanur pada suhu 750 ${ }^{\circ} \mathrm{C}$ dan selama 5 jam. Setelah 5 jam selanjutnya dimasukkan desikator selama 15 menit. Abu yang tersisa di wadah ditimbang dan dihitung menggunakan persamaan (2).

$\%$ kadar abu $=\frac{\left(W_{3}-W_{1}\right)}{\left(W_{2}-W_{1}\right)} \times 100 \%$

$\%$ kadar abu $=$ persentase abu pada sampel $(\%)$

$\mathrm{W}_{1}=$ berat wadah kosong (gram)

$\mathrm{W}_{2}=$ berat wadah + sampel (gram)

$\mathrm{W}_{3}=$ berat wadah + residu $(\mathrm{gram})$

\subsubsection{Analisis Calorific Value (ASTM} standar D 5865-07a, cal/gr)

Satu gram biobriket ampas kopi ditimbang dalam cawan, lalu ditempatkan pada IKA C-2000 bomb calorimeter. 10 $\mathrm{cm}$ benang pembakar dari katun dipasang pada kawat penghubung kedua kutub bomb head, pelintir benang sampai ujungnya menyentuh biobriket. Bomb head yang 
Pengaruh Suhu dan Jenis Perekat Terhadap Kualitas Biobriket dari Ampas Kopi dengan Metode Torefaksi

berisi biobriket dimasukan kedalam alat kalorimeter, kemudian memutarnya sampai tertutup dan terkunci. Selanjutnya Tekan tombol "start", lalu tekan tombol "continue", memasukkan nama kode atau ID sampel biobriket kemudian tekan enter. Melihat ID bomb sesuaikan dengan kode bomb head-nya lalu tekan enter dan ketik bobot biobriket kemudian tekan enter lagi. Nilai kalor otomatis tercetak yang menandakan proses telah selesai.

\section{Hasil dan Pembahasan}

Ampas kopi berasal dari restoran atau industri kopi dapat dikategorikan dalam limbah argoindustri. Ampas kopi memiliki kandungan hidrokarbon menjadi poin utama sebagai bahan baku energi alternatif. Sebelum mengetahui kualitas biobriket yang dibuat berdasarkan pengaruh jenis dan jumlah perekat menggunakan metode torefaksi, perlu diadakan uji ultimat dan nilai kalor dari ampas kopi yang akan digunakan sebagai bahan biobriket. Hasil uji ultimat yang telah dilakukan pada Laboratorium Tekmira Bandung ditunjukkan pada Gambar 1.

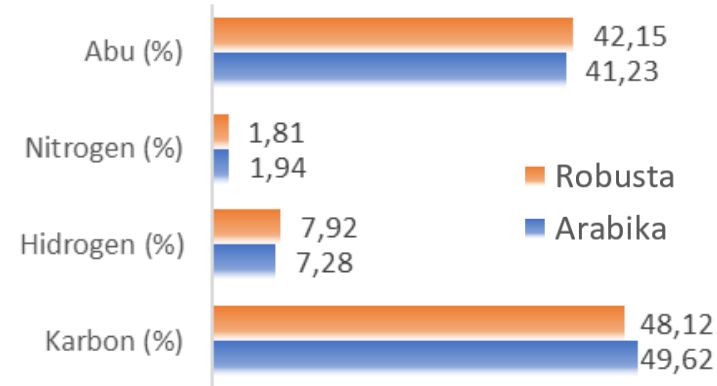

Gambar 1. Hasil Uji Ultimat Ampas Kopi

Gambar 1 menunjukkan bahwa ampas kopi arabika memiliki 7,28\% hidrogen, 1,94\% nitrogen, 49,62\% karbon dan $41,23 \%$ bahan yang tidak terbakar seperti selulosa, oksigen atau abu. Pada penelitian menggunakan ampas kopi jenis arabika karena kandungan karbon pada ampas kopi arabika lebih banyak dibandingkan dengan ampas kopi robusta. Ampas kopi arabika tersebut juga memiliki nilai kalor sekitar 3489,51 kal/gr sehingga perlu ditingkatkan dengan salah satu cara seperti metode torefaksi. Kandungan kimia organik yang telah dianalisis sesuai dengan hasil penelitian Baryatik $d k k$. [13] yaitu karbon sebesar 47,8-58,9 \%, nitrogen sebesar 1,9-2,3\%, abu sebesar 0,43-1,6\% dan selulosa $8,6 \%$.

Ampas kopi yang telah dianalisis dengan kandungan karbon sekitar 49,62\% tersebut dikeringkan terlebih dahulu sebelum dicampur dengan perekat sesuai variabel penelitian. Setelah dicetak, ampas kopi tersebut dipanaskan dengan reaktor pemanas yang membantu proses pengikatan partikel-partikel biomassa. Selain itu, diperkuat dengan penambahan perekat untuk membentuk ikatan antar partikel-partikel biomassa. Perekat yang akan digunakan ada dua jenis yaitu tepung tapioka dan getah pinus. Bentuk silinder pada biobriket dipilih karena mempermudah dalam proses pembriketan. Selain itu, bentuk ini sangat umum terdapat dipasaran.

Pada umumnya, tepung tapioka digunakan sebagai perekat biobriket karena mudah ditemukan, relatif murah, dan cara penggunaannya mudah yaitu cukup dicampurkan dengan air lalu dipanaskan. Selama pemanasan, tapioka diaduk agar tidak menggumpal. Warna tapioka yang putih akan berubah menjadi tidak berwarna setelah beberapa menit dipanaskan dan terasa lengket [10]. Analisis proksimat dari tepung tapioka tercantum pada Gambar 2. 
Pengaruh Suhu dan Jenis Perekat Terhadap Kualitas Biobriket dari Ampas Kopi dengan Metode Torefaksi

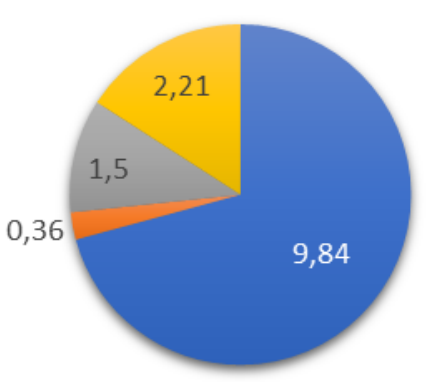

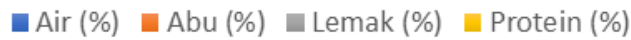

Gambar 2. Analisis Proksimat Tepung Tapioka

Perekat getah pinus sifat fisiknya relatif sama dengan biobriket arang yang menggunakan getah karet. Kelebihan perekat dari getah pinus adalah daya benturannya yang relatif kuat dan mudah menyala saat dibakar. Namun kekurangan dari perekat ini adalah asap yang dihasilkan relatif banyak dan bau yang cukup menyengat [13].

Biobriket yang sudah dicetak selanjutnya dipanaskan pada reaktor torefaksi. Torefaksi berlangsung saat tekanan atmosfir dan rentang suhu yang diatur antara 200-350 ${ }^{\circ} \mathrm{C}$ [15]. Peningkatan suhu torefaksi akan berakibat pada komponen volatil yang bertambah akibat dari hasil pemecahan hemiselulosa, lignin, dan selulosa. Suhu torefaksi mempengaruhi komposisi dan hasil dari produk. Suhu rendah menghasilkan lebih banyak arang, suhu tinggi menghasilkan lebih sedikit arang [16].

Pada komponen kopi, sukrosa, polisakarida, gula pereduksi, protein, dan pektin akan cepat terdekomposisi pada suhu rendah dan lignin pada suhu tinggi. Lignin merupakan polimer kompleks [17] Menurut Basu [12] lignin dapat terdekomposisi pada temperatur 250-500 ${ }^{\circ} \mathrm{C}$ sedangkan sukrosa, polisakardia, gula pereduksi, protein, dan pektin merupakan rantai karbon sederhana dan akan langsung terdekompoisisi pada suhu rendah.

Pengukuran moisture content biobriket dilakukan setelah dikempa dan dikeringkan. Moisture content dalam pembuatan biobriket cukup berpengaruh terhadap kualitas biobriket. Semakin tinggi moisture content menyebabkan kualitas biobriket menurun, terutama berpengaruh terhadap calorific value biobriket dan akan lebih sulit untuk dinyalakan. Hal ini disebabkan karena energi yang dihasilkan akan lebih terserap untuk menguapkan air yang terkandung pada biobriket [17]. Hasil analisis kadar air ditunjukkan pada Gambar 3.

Menurut standar SNI 01-6235-2000 nilai kadar air maksimum pada biobriket sebesar $8 \%$. Pada penelitian ini didapatkan biobriket dengan nilai kadar air kurang dari $8 \%$. Hal tersebut menunjukkan bahwa biobriket yang dihasilkan memenuhi standar SNI 01-6235-2000. Kadar air terendah yang dihasilkan pada biobriket yaitu tanpa perekat tepung tapioka (konsentrasi 0\%) sekitar 0,8156\% sedangkan yang tertinggi pada biobriket menggunakan tepung tapioka $20 \%$ sebesar $7,7600 \%$. Sedangkan berdasarkan komposisi perekat, kadar air tertinggi didapatkan pada komposisi perekat tepung tapioka sebesar $20 \%$ dan terendah didapatkan pada komposisi perekat getah pinus sebesar $40 \%$.

Menurut Fitri [18] biobriket dengan perekat $40 \%$ getah pinus memiliki kadar air 3,93\%. Hal ini menunjukkan hubungan yang berbanding lurus antara konsentrasi perekat dengan kadar air biobriket ampas kopi. Hasil yang didapat pada penelitian ini sesuai dengan teori yaitu semakin tinggi komposisi perekat yang digunakan maka semakin besar kadar air pada biobriket. Semakin banyak perekat yang digunakan 


\section{Pengaruh Suhu dan Jenis Perekat Terhadap Kualitas Biobriket dari Ampas Kopi dengan Metode} Torefaksi

maka semakin banyak jumlah air yang dibutuhkan untuk mengubah perekat sehingga kadar air pada biobriket pun akan besar. Namun biobriket yang dihasilkan dengan menggunakan perekat getah pinus memiliki karakteristik yang berbeda dikarenakan perekat getah pinus memiliki
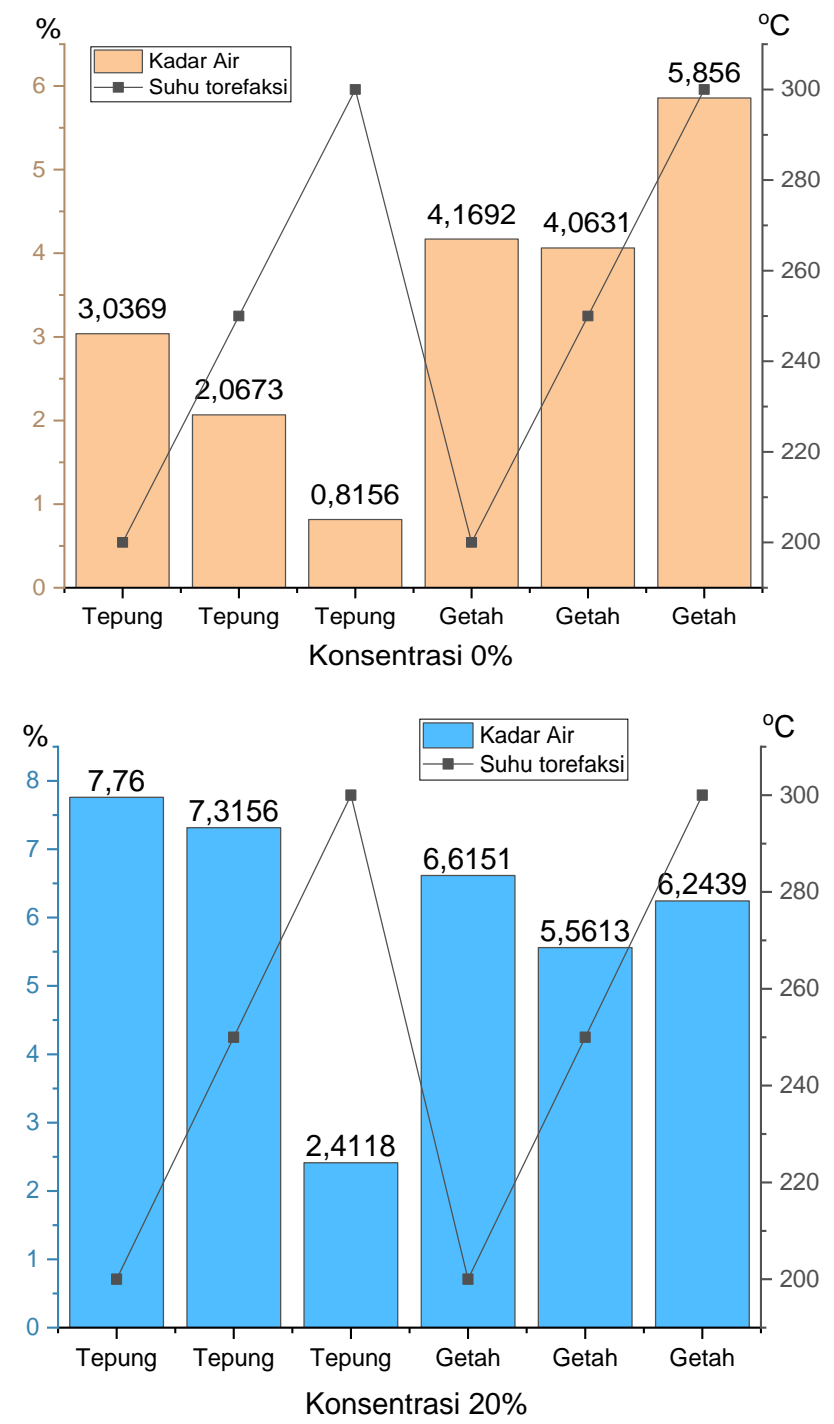

sifat hidrofobik [19]. Hal tersebut dapat ditunjukkan pada hasil penelitian bahwa kadar air pada biobriket dari ampas kopi dengan perekat getah pinus relatif lebih rendah dibandingkan biobriket ampas kopi dengan perekat tepung tapioka.
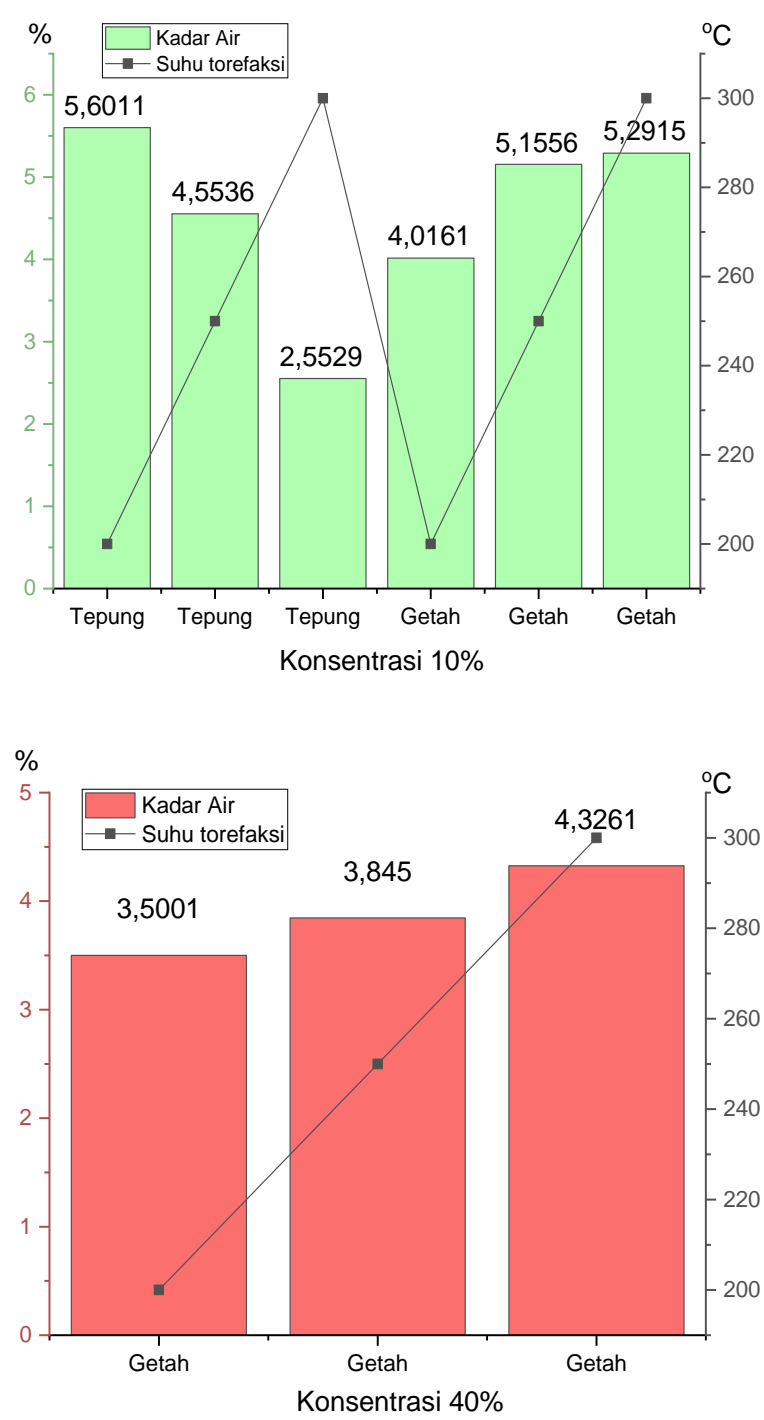

Gambar 3. Kadar Air Biobriket dari Ampas Kopi

Hasil analisis kadar abu dapat dilihat pada Gambar 4. Berdasarkan hasil tersebut, semakin tinggi suhu torefaksi yang digunakan, maka semakin tinggi ash content yang terkandung pada biobriket. Menurut standar SNI 01-6235-2000 nilai kadar abu maksimum pada biobriket sebesar 8\%. Pada penelitian ini didapatkan biobriket dengan nilai kadar abu kurang dari $8 \%$. Hal tersebut menunjukkan bahwa biobriket yang dihasilkan baik menggunakan perekat tepung tapioka maupun getah pinus memenuhi standar SNI 01-6235-2000. 
Pengaruh Suhu dan Jenis Perekat Terhadap Kualitas Biobriket dari Ampas Kopi dengan Metode Torefaksi

Selain pengaruh dari suhu torefaksi dan jumlah perekat, nilai ash content dapat dipengaruhi oleh impurities yang berada dalam air pembuat perekat sehingga komponen mineral biobriket relatif meningkat dan saat torefaksi menghasilkan ash sebagai sisa dari pembakaran. Kadar abu tertinggi pada penelitian ini terdapat pada biobriket dengan perekat getah pinus $20 \%$ yaitu sebesar 5,1432\%. Berbeda dengan hasil penelitian yang dilakukan oleh Fitri [18], biobriket dari kulit kopi dengan perekat getah pinus memiliki kadar abu $0,271 \%$. Hal ini dikarenakan kulit dari kopi mempunyai komponen organik yang tinggi sehingga mudah untuk terikat pada
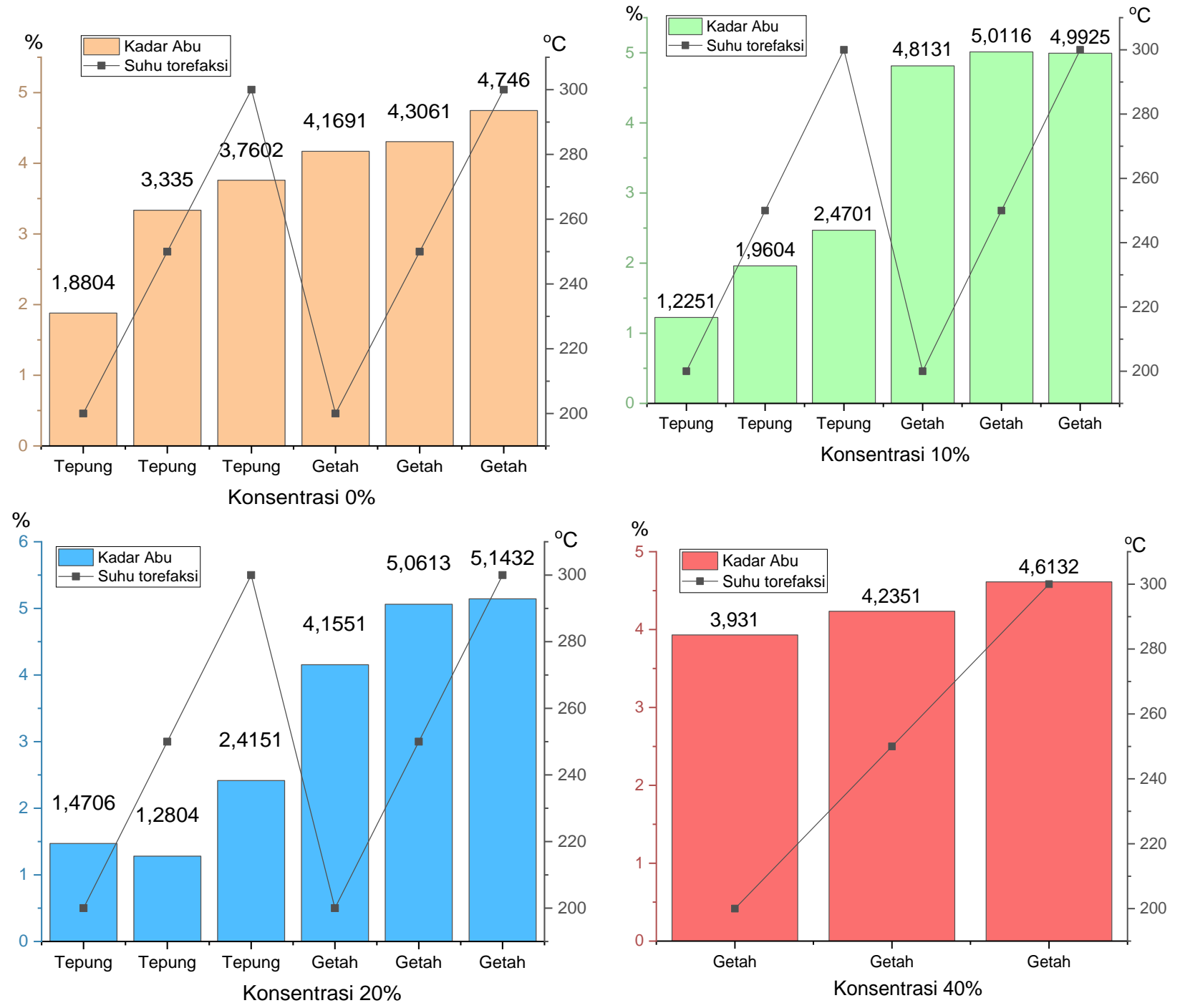

Gambar 4. Kadar Abu Biobriket dari Ampas Kopi 
Pengaruh Suhu dan Jenis Perekat Terhadap Kualitas Biobriket dari Ampas Kopi dengan Metode Torefaksi

Pengukuran nilai kalor bertujuan untuk mengetahui nilai kalor pembakaran yang dihasilkan oleh biobriket dari ampas kopi. Analisis nilai kalor suatu bahan bakar padat maupun cair bertujuan untuk memperoleh data tentang energi panas yang dapat dihasilkan oleh suatu bahan bakar dengan terjadinya reaksi atau proses pembakaran [21]. Purnomo dkk. [22] menyatakan bahwa nilai kalor merupakan
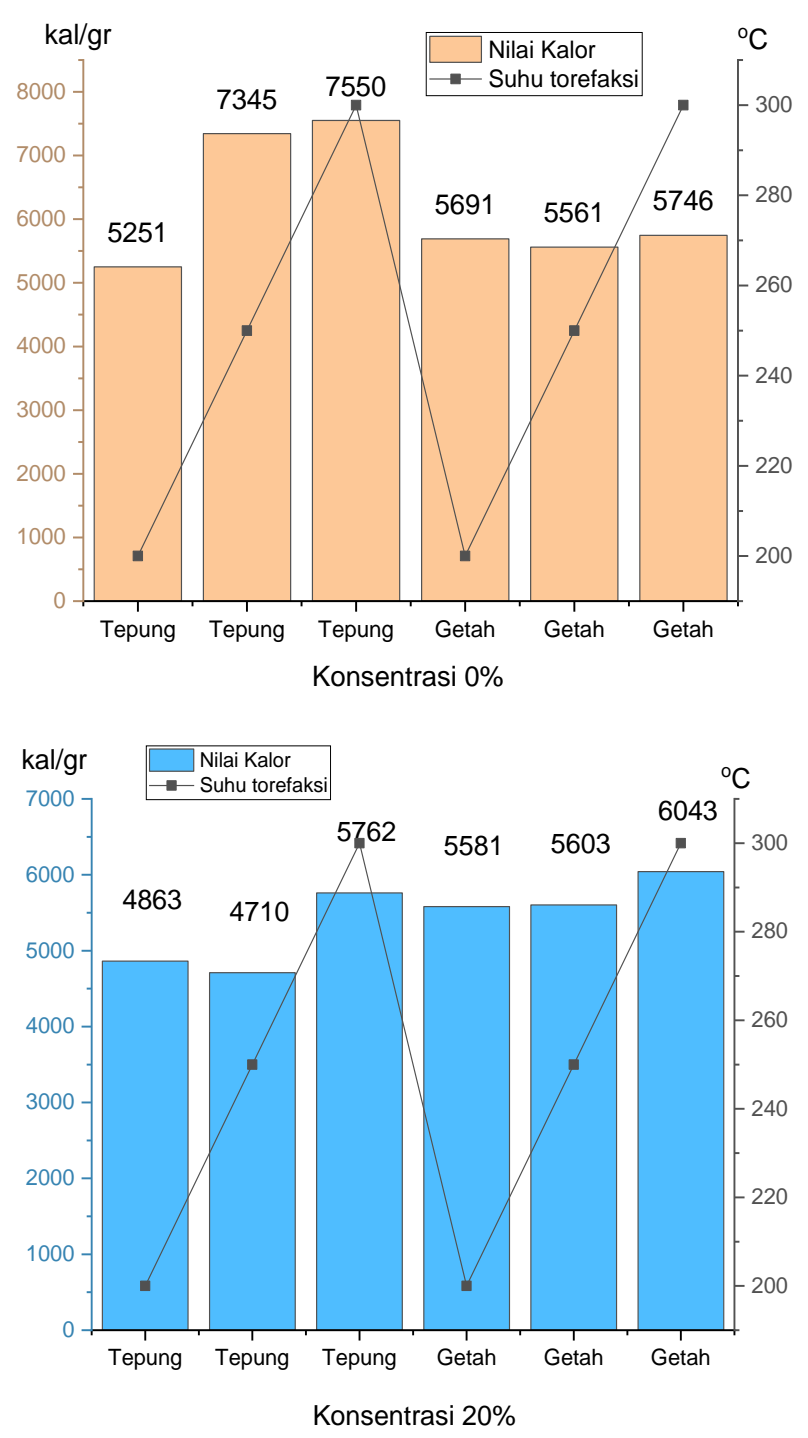

parameter khusus yang paling penting untuk mengetahui kualitas biobriket sebagai bahan bakar padat. Semakin tinggi nilai kalor biobriket, semakin baik pula kualitasnya [22]. Berdasarkan SNI 016235-2000, nilai kalor untuk biobriket yang baik adalah di atas $5000 \mathrm{kal} / \mathrm{gr}$. Hasil analisis nilai kalor biobriket dari ampas kopi dapat dilihat pada Gambar 5.
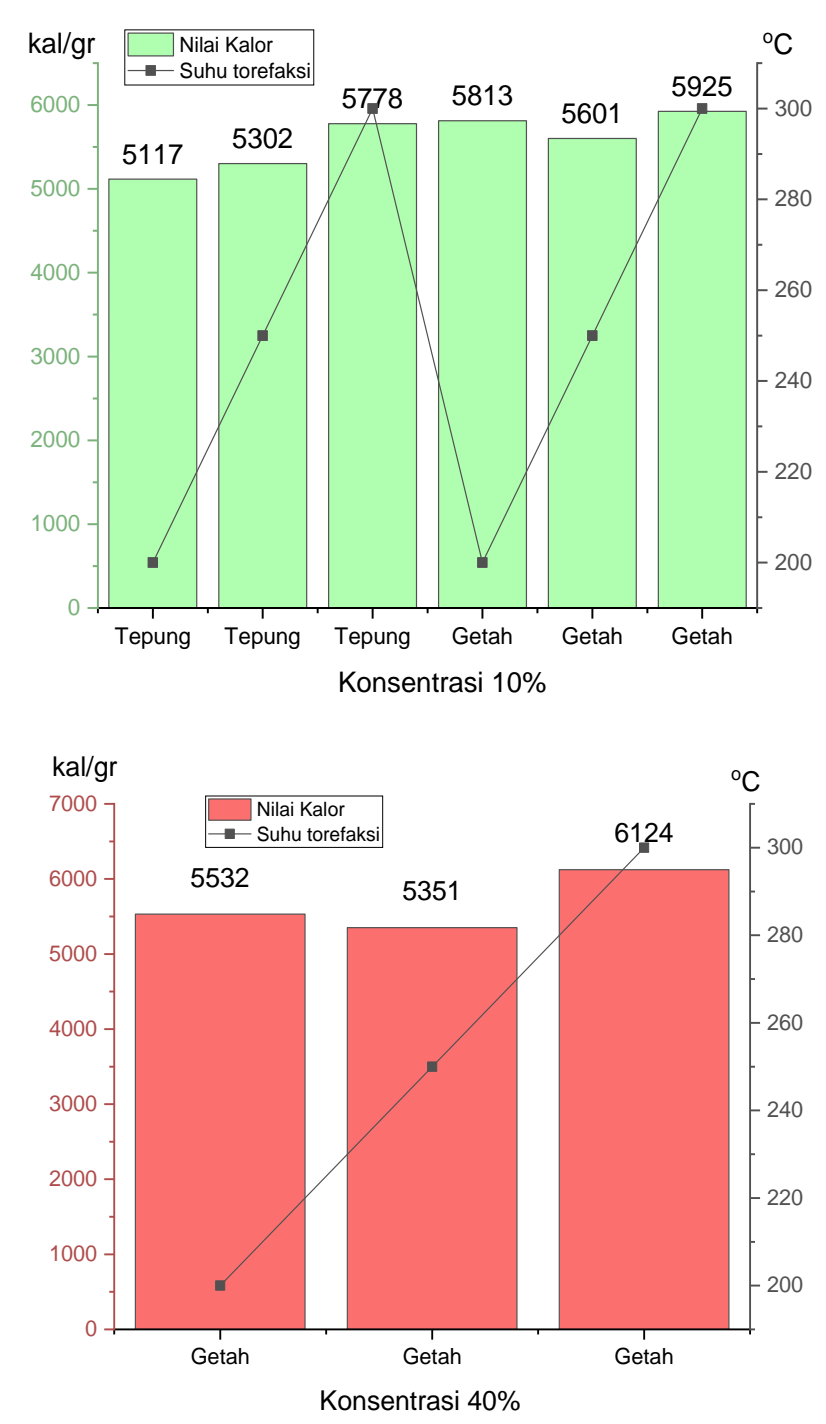

Gambar 5. Nilai Kalor Biobriket dari Ampas Kopi

Menurut teori, semakin tinggi suhu yang digunakan pada proses torefaksi maka semakin besar juga nilai kalor yang dimiliki oleh biobriket ampas kopi [12]. Pane $d k k$. [23] menyatakan bahwa semakin kecil konsentrasi perekat maka akan menghasilkan nilai kalor optimum.

Gambar 5 menunjukkan turunnya nilai kalor yang dipengaruhi oleh berkurangnya jumlah/konsentrasi ampas 
Pengaruh Suhu dan Jenis Perekat Terhadap Kualitas Biobriket dari Ampas Kopi dengan Metode Torefaksi

kopi saat proses torefaksi berlangsung, dapat diartikan bahwa komposisi bahan biobriket memberikan pengaruh terhadap nilai kalor yang dihasilkan. Hal tersebut dapat terjadi karena penambahan perekat yang semakin tinggi menyebabkan air yang terkandung dalam perekat akan masuk dan terikat dalam pori biobriket, selain itu penambahan perekat yang semakin tinggi akan menyebabkan biobriket mempunyai kerapatan yang semakin tinggi pula sehingga pori-pori biobriket semakin kecil dan pada saat dilakukan proses torefaksi air yang terperangkap di dalam pori biobriket sukar menguap [24].

Nilai kalor tertinggi terdapat pada biobriket yang dibuat menggunakan perekat tepung tapioka $0 \%$ pada suhu torefaksi $300 \quad{ }^{\circ} \mathrm{C}$ yaitu $7550 \quad \mathrm{kal} / \mathrm{gr}$. Sedangkan pada biobriket yang menggunakan getah pinus memiliki nilai kalor tertinggi pada suhu torefaksi $300{ }^{\circ} \mathrm{C}$ dengan perekat $40 \%$ sebesar $6124 \mathrm{kal} / \mathrm{gr}$. Hasil tersebut sama dengan hasil penelitian Fitri [18] yaitu nilai kalor untuk biobriket dari limbah kulit kopi menggunakan perekat getah pinus menghasilkan 6124 kal/gr. Hasil tersebut terdapat pada biobriket (70:30), sedangkan nilai kalor terendah sebesar $5532 \mathrm{kal} / \mathrm{gr}$ terdapat pada biobriket (10:90).
Berdasarkan SNI 01-6235-2000, nilai kalor untuk biobriket yang baik adalah di atas $5000 \mathrm{kal} / \mathrm{gr}$, sehingga biobriket yang didapatkan pada penelitian ini sudah memenuhi standar kecuali pada biobriket dengan tepung tapioka $20 \%$ dengan suhu pembakaran $250{ }^{\circ} \mathrm{C}$ dan $300{ }^{\circ} \mathrm{C}$. Nilai kalor pada biobriket dengan perekat getah pinus memiliki kecenderungan meningkat dengan penambahan konsentrasi getah pinus, hal ini dikarenakan getah pinus memiliki nilai kalor lebih tinggi dibandingkan tepung tapioka sehingga dapat meningkatkan nilai kalor dari biobriket [13].

\section{Kesimpulan}

Suhu torefaksi optimum untuk pembuatan biobriket dari ampas kopi adalah $300{ }^{\circ} \mathrm{C}$ tanpa menggunakan perekat yang menghasilkan nilai kalor sebesar $7550 \mathrm{kal} / \mathrm{gr}$. Namun pada biobriket ampas kopi dengan perekat getah pinus $40 \%$ memiliki nilai kalor tertinggi sebesar 6124 $\mathrm{kal} / \mathrm{gr}$. Sehingga dalam pembuatan biobriket dari ampas kopi lebih baik menggunakan suhu torefaksi pada suhu $300{ }^{\circ} \mathrm{C}$ dengan perekat getah pinus sebesar $40 \%$ supaya biobriket yang dihasilkan cukup padat dan kokoh.

\section{Daftar Rujukan}

[1] Parinduri, L., \& Parinduri, T. (2020). Konversi Biomassa Sebagai Sumber Energi Terbarukan. JET (Journal of Electrical Technology), 5(2), 88-92. Retrieved from https://jurnal.uisu.ac.id/index.php/jet/article/view/2885

[2] Aprita, I. R. (2016). Produksi Biopelet Dan Biobriket Ampas Seduhan Dan Cangkang Biji Kopi Dengan Dan Tanpa Pra Perlakuan Bahan Pada Berbagai Komposisi Perekat. Bogor Agricultural University. Retrieved from http://repository.ipb.ac.id/handle/123456789/82767

[3] Suhartini, S., Hidayat, N., \& Wijaya, S. (2011). Physical properties characterization of fuel briquette made from spent bleaching earth. Biomass and Bioenergy, 35(10), 4209-4214. doi: 10.1016/j.biombioe.2011.07.002

[4] Ryu, C., Yang, Y. Bin, Khor, A., Yates, N. E., Sharifi, V. N., \& Swithenbank, J. (2006). Effect of fuel properties on biomass combustion: Part I. Experiments - Fuel type, equivalence ratio and particle size. Fuel, 85(7-8), 1039-1046. doi: 10.1016/j.fuel.2005.09.019 
[5] Hachicha, R., Rekik, O., Hachicha, S., Ferchichi, M., Woodward, S., Moncef, N., ... Mechichi, T. (2012). Co-composting of spent coffee ground with olive mill wastewater sludge and poultry manure and effect of Trametes versicolor inoculation on the compost maturity. Chemosphere, 88(6), 677-682. doi: 10.1016/j.chemosphere.2012.03.053

[6] Romeiro, G. A., Salgado, E. C., Silva, R. V. S., Figueiredo, M. K. K., Pinto, P. A., \& Damasceno, R. N. (2012). A study of pyrolysis oil from soluble coffee ground using low temperature conversion (LTC) process. Journal of Analytical and Applied Pyrolysis, 93, 47-51. doi: 10.1016/j.jaap.2011.09.006

[7] Tsai, W. T., Liu, S. C., \& Hsieh, C. H. (2012). Preparation and fuel properties of biochars from the pyrolysis of exhausted coffee residue. Journal of Analytical and Applied Pyrolysis, 93, 6367. doi: 10.1016/j.jaap.2011.09.010

[8] Khusna, D., \& Susanto, J. (2015). Pemanfaatan Limbah Padat Kopi Sebagai Bahan Bakar Alternatif Dalam Bentuk Briket Berbasis Biomass (Studi Kasus di PT. Santos Jaya Abadi Instan Coffee). Seminar Nasional Sains dan Teknologi Terapan III 2015, Institut Teknologi Adhi Tama Surabaya, 247-260. Retrieved from https://www.google.com/url?sa=t\&rct=j\&q=\&esrc=s\&source=web\&cd=19\&ved=2ahUKEwiD _o66uYzkAhVRjOYKHaHBAl4QFjASegQIARAC\&url=http\%3A\%2F\%2Fjurnal.itats.ac.id\%2 Fwp-content\%2Fuploads\%2F2015\%2F11\%2F28.-Dwi-

kusna_itats1.pdf\&usg=AOvVaw0MJGMzM_NljIcys61yC7hQ

[9] Pratiwi, V. D., Isnaeni, I., Pratiwi, D. (2020). Variasi Perekat Dan Waktu Pemanasan Pada Biobriket Dari Ampas Kopi. (Laporan Penelitian Dosen, Institut Teknologi Nasional Bandung).

[10] Pratiwi, V. D. (2020). Effect of Burning Temperature on The Quality of Alternatife Bio-energy from Coffee Waste. ELKOMIKA: Jurnal Teknik Energi Elektrik, Teknik Telekomunikasi, \& Teknik Elektronika, 8(3), 615. doi: 10.26760/elkomika.v8i3.615.

[11] Batoro, J. (2015). Pengelolaan Lingkungan Dengan Pendekatan Etnobiologi-Etnobotani (1st ed.). Malang: University of Brawijaya Press.

[12] Basu, P. (2010). Biomass Gasification and Pyrolysis - 1st Edition. elsevier (1st ed.). united states: Academic Press. Retrieved from https://www.elsevier.com/books/biomass-gasificationand-pyrolysis/basu/978-0-12-374988-8

[13] Baryatik, P., Pujiati, R. S., \& Ellyke. (2016). Pemanfaatan Arang Aktif Ampas Kopi sebagai Adsorben Logam Kromium (Cr) pada Limbah Cair Batik (Studi Kasus Industri Batik UD. Pakem Sari Desa Sumberpakem Kecamatan Sumberjambe Kabupaten Jember). Artikel Ilmiah Hasil Penelitian Mahasiswa 2016, 1(1), 1-6. Retrieved from https://repository.unej.ac.id/bitstream/handle/123456789/77363/PuputBaryatik.pdf?sequence=1 \&isAllowed $=\mathrm{y}$

[14] Lubis, H. A. (2011). Uji Variasi Komposisi Bahan Pembuat Briket Kotoran Sapi dan Limbah Pertanian. Retrieved from http://repository.usu.ac.id/handle/123456789/28807

[15] Bergman, P. C. A., Boersma, A. R., Zwart, R. W. R., \& Kiel, J. H. A. (2005). Torrefaction for biomass co-firing in existing coal-fired power stations. BIOCOAL. https://www.osti.gov/etdeweb/biblio/20670903

[16] Maharsa, L., \& Muhammad, M. (2012). Pengaruh Variasi Komposisi Campuran Pada Biobriket Kulit Mete Dan Sekam Padi Terhadap Laju Pembakaran. ROTASI, 14(4), 15-22. doi: 10.14710/ROTASI.14.4.15-22

[17] Chu, Y. (2013). Coffee: Emerging Health Effects and Disease Prevention. Wiley. Retrieved from https://www.wiley.com/enus/Coffee\%3A+Emerging+Health+Effects+and+Disease+Prevention-p-9780470958780

[18] Fitri, N. (2017). Pembuatan Briket dari Campuran Kulit Kopi (coffea arabica) dan Serbuk Gergaji dengan Menggunakan Getah Pinus Sebagai Perekat. (Skripsi, Universitas Islam Negeri Alauddin Makassar). http://repositori.uin-alauddin.ac.id/7064/

[19] Suranto, Y. (2018). Karakter Dan Kualitas Gondorukem Kuna Hasil Penemuan Di Pemukiman Pecinan Kutoarjo Kabupaten Purworejo. Jurnal Konservasi Cagar Budaya, 12(2), 47-60. doi: 10.33374/jurnalkonservasicagarbudaya.v12i2.188

[20] Bezanson, A. 2009. Pyrolysis and Torrefaction of Biomass. Canada: Dalhousie University. 
[21] Ali, N. J., Anas, M., \& Erniwati. (2020). Pengaruh Variasi Bahan Perekat terhadap Nilai Kalor dan Waktu Nyala Briket Arang Ban Bekas. Jurnal Penelitian Pendidikan Fisika, 5(4), 334-338.

[22] Purnomo, R. H., Hower, H., \& Rizki Padya, I. (2015). Pemanfaatan limbah biomassa untuk briket sebagai energi alternatif. Prosiding Seminar Agroindustri dan Lokakarya Nasional FKPT-TPI, (September), 54-67. Retrieved from http://tip.trunojoyo.ac.id/semnas/wpcontent/uploads/B54-B67-Rahmad-Hari-Purnomo_Univ-Sriwijaya.pdf

[23] Pane, J. P., Junary, E., \& Herlina, N. (2015). Pengaruh Konsentrasi Perekat Tepung Tapioka Dan Penambahan Kapur Dalam Pembuatan Briket Arang Berbahan Baku Pelepah Aren (Arenga Pinnata). Jurnal Teknik Kimia USU, 4(2), 32-38. doi: 10.32734/jtk.v4i2.1468

[24] Alamsyah, R., Siregar, N. C., \& Hasanah, F. (2018). Peningkatan Nilai Kalor Pellet Biomassa Cocopeat sebagai Bahan Bakar Terbarukan dengan Aplikasi Torefaksi. Warta Industri Hasil Pertanian, 33(01), 17-23 